\title{
シリコーンゴムにおけるトラブル 事例とその対策
}

角 村 真 一*

\section{1.はじめに}

シリコーンゴムは面白くないとの声をゴム屋さ んからよく聞かされる。配合技術が生かせない, 合成ゴムでの配合経験があまり役に立たない, 競 合他社との優位性が出せないなどが理由のようで ある．確かに欧米ではべース売りの形態もあり， 各種充てん剂や添加剂をコンパウンダーが混ぜて いる例もあるが，アジアでは圧倒的にコンパウン ド売りが多い.シリコーンゴム独特の配合, 混練 機が他のゴムと異なること，また最終ユーザーさ んの要望に応える際にシリコーンポリマーメーカ 一, 成形加工メーカー, エンドューザーの 3 者が 一体で活動することが新製品開発や問題解決速度 を早めることにつながるためと考えている.

シリコーンゴムにおけるトラブルについて機能 から来るものと成形上のものとに分けて考察した い. 機能面のトラブルはシリコーンゴムのもつ性 質を理解しておくことで防止できる可能性があ り，これがシリコーンゴムに永年携わってきた者 の強みである。一方, 成形上のトラブルは離型性 やエア溜りなど予想のつかないことが多く, 実際 に成形してみないと解決への糸口すら分からない こともある. 成形加工メーカーさんに依存する部 分が多く，かつ定量的な議論ができるデー夕をも たず，力不足であるが，過去の事例の紹介と対策 を述べ，参考にして頂ければ幸いである。

\section{2. 機能面のトラブル}

\section{1 透過性}

$\mathrm{Si}-\mathrm{O}$ 結合の距離は $1.64 \AA$ と $-\mathrm{C}$ 結合の
$1.54 \AA$ より長い, また $\mathrm{Si}-\mathrm{O}-\mathrm{Si} の$ 結合角は 130 160 度とポリエチレンの 110 度に比べて大 きい.このためシリコーンゴムは一般的に気体透 過性が良く, 一液のシーラントが空気中の湿気と 反応して硬化が進むのもこの性質を利用してい る.したがって，シリコーンゴムはタイヤチュー ブやガス管には使用できない.トラブルとしては 他の素材からの色の移行や油脂の透過がある. シ リコーンゴムと接触していたプラスチックスから 色が移行したり，他の合成ゴムからブリードした 老化防止剂などがシリコーンゴムに移行し, シリ コーンゴムを劣化させた事例がある. 原子吸光な どで分析すると移行した部分から硫黄やアミンが 多く検出されることがある．熱天びんによる分析 も有力かつ安易な方法で正常部と異常部の重量減 少挙動を比較することで原因を特定することがで きる場合が多い. 硫黄やアミンはシリコーンポリ マ一の主鎖の切断を招く懸念があり，接触しない ようにするなどの対策が必要である。

ラードを用いた簡単な透過実験でも透過が確認 される. 油脂が絶縁部のシリコーンゴムを透過

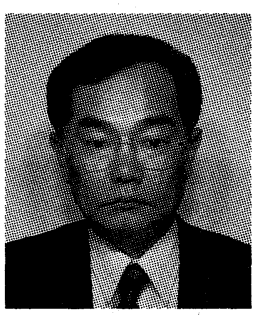

*東レ・ダウコーニング・シリコー ン侏)(テ299-0108 市原市千種海岸 2-2) 研究開発本部開発部部長. 昭 和 49 年東京大学工学部工業化学科 修士課程卒業, 同年トーレ・シリ コーン侏現東レ・ダウコーニン グ・シリコーン侏入社, 現在に至 る.

専門は高分子化学, シリコーンゴ 厶.

日本ゴム協会関東支部副支部長. 


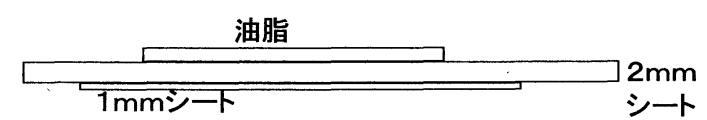

図 1 シリコーンゴムの浸透試験 油脂の浸透を FT-IR で調查

$1 \mathrm{~mm}$ シートをはがし, 経時で浸透す

る量を測定(エステルのピーク)

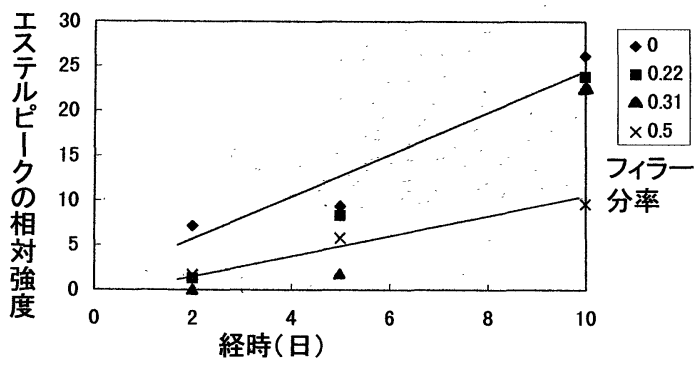

図 2 シリコーンゴムの浸透試験
ている. 主鎖のイオン性が高いことは, 凝集力が 高いという特徴のある反面，イオン的な攻撃に必 ずしも強くないことを意味している．中性雾囲気 下では非常に高い耐熱性を示すシリコーンゴムも 酸や塩基が存在すると低温でも容易に分解するこ とがある。

シリコーンゴムの熱的劣化は側鎖のメチル基か らの $\mathrm{H}$ 原子引き抜きに端を発すると考えられる 硬化劣化と鎖が切断すると考えられる軟化劣化が ある．前者は金属酸化物やラジカル捕捉剂などで 改善され，後者はイオン性の不純物をできるだけ 排除する方法が有力である．白化現象のトラブル はカルシウムや塩素などのイオン攻撃により，ポ リシロキサンが解重合を起こし，モノマーとなっ て表面から一部離脱し，充てん剂である二酸化ケ イ素が観察されたと推定している。またシリコー ンゴム裏面のべたつきも同じくシリコーンオリゴ マーが析出したと考えられる. 耐溶剤性に優れる
し，導電ゴム表面に析出し，導通不良となっ た事例がある。図 1 に油脂を用いた浸透試験 の方法を示し, 結果を図 2 に示した. シリコ ーンゴム中のフィラー分率を上げることで透 過性を押さえることはできるが，透過をなく すことは困難である.フィルムなどを挟むサ ンドウィッチ構造で対策とすることが可能で ある。

\section{2 耐熱性}

シリコーンゴムはポリジオルガノシロキサ ン(シリコーンポリマー)を主原料として，乾 式シリカ, 湿式シリカなどの補強充てん剂, 珪藻土, 石英粉末などの増量充てん剂, 種々 の添加剂，架橋剤などを加えている．天然ゴ ム，合成ゴムに比へ，特に耐熱性に優れてい るが，耐熱性に関するトラブルは意外と多 い. シリコーンゴムの白化現象，表面のべた つきなどの事例がある。実用上の耐熱性に は, 結合エネルギーで論じる ‘熱的安定性’の 他に，酸化などに対する ‘化学的安定性”をも 考慮する必要がある．ポリシロキサンはイオ ン性が高い. Si 原子は周期律表では C と同 じ族であるが，Cより金属性が大きく，周囲 の電子を引き付ける強さが小さい(電気陰性 度が小さい)。電子は $\mathrm{O}$ 原子の周りに偏在 し, $\mathrm{Si}$ が十, $\mathrm{O}$ がーに分極した構造になっ

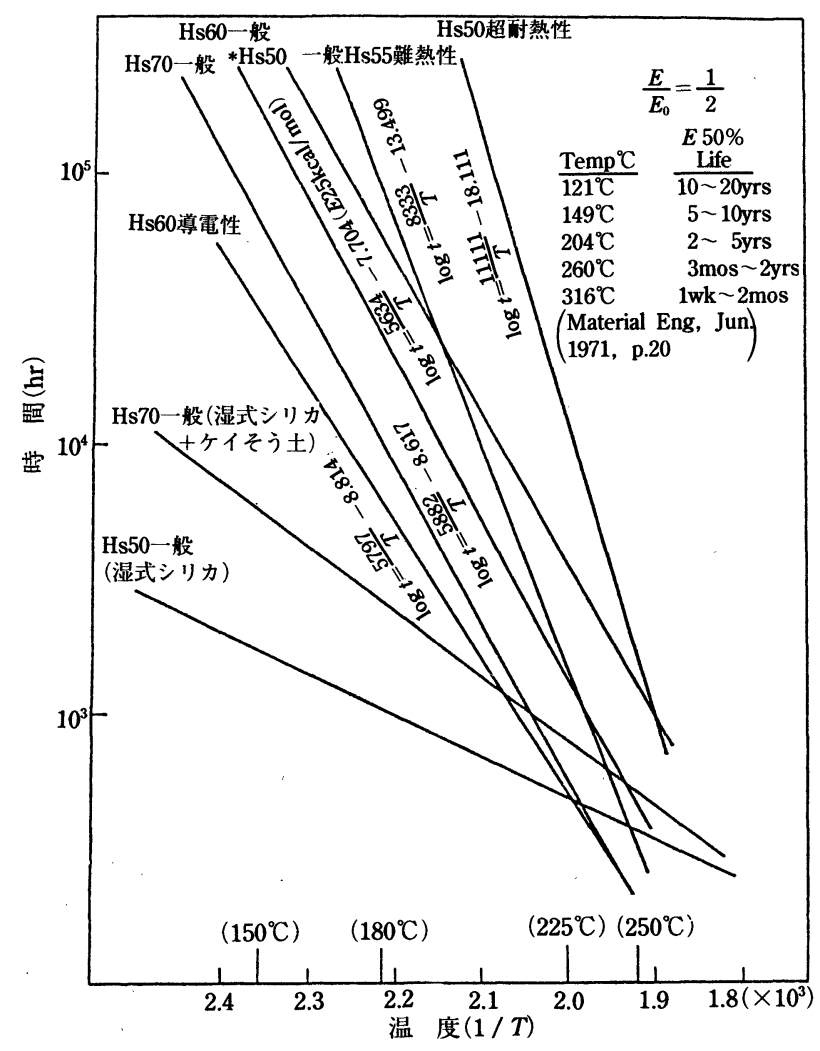

困 3 シリコーンゴムの耐熱寿命 


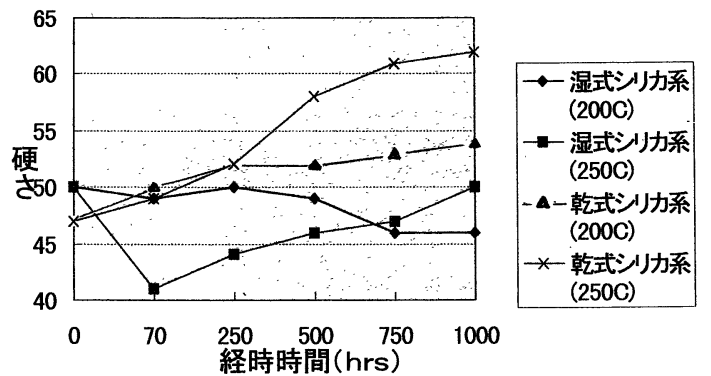

囷 4 シリコーンゴムの耐熱性

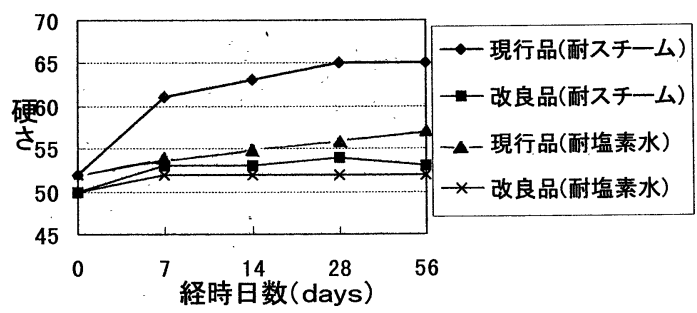

図 5 シリコーンゴムの耐スチーム性, 耐塩素水性

フロロシリコーンゴムの場合でもイオン性の攻撃 には必ずしも強くない場合もあり，トラブル事例 に応じて，受酸剂などで解決できる場合も多い が，強塩基の雾囲気では良好な対策がないのが実 状と思われる。図 3 に乾式シリカ, 湿式シリカに よる耐熱性の違いを示した ${ }^{1)}$ 。乾式シリカ使用の シリコーンゴムがアウレニウスプロットによる耐 熱性では湿式シリカ使用のシリコーンゴムを上回 っている．ただ湿式シリカのなかでも特にシリコ ーンゴム用としてイオン性不純物の少ないものを 選択すると，図 4 に示すように $250^{\circ} \mathrm{C}$ の条件でも 耐久性がある。棟で生産されるシリコーンゴム 用湿式シリカの品質は $\mathrm{Na}, \mathrm{K}$ などの洗浄に用い る軟水が優れるため，世界一であろう。

耐スチ一么性，耐塩素水性でもイオン性の不純 物は大きな要素である。フィラーの純度をあげる ことで改良できる例を図 5 に示した。 シリコーン ゴムの配合ではフィラーの影響を受けることが大 きく，ポリマーメーカーではフィラーメーカーと の連携によって改良を重ねてきた。

\section{3 接点障害, 污染}

シリコーン生ゴムの重合原料には，ジオルガノ ジクロロシランを加水分解して得られるハイドロ リゼートから分留された環状ジオルガノシロキサ

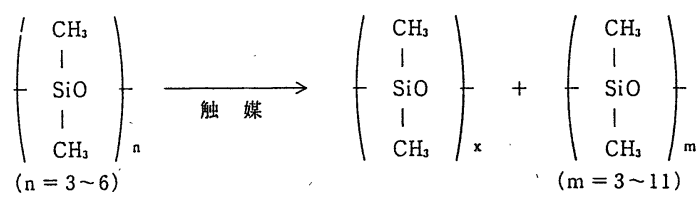

困 6 シリコーン生ゴムの重合反応

表 1 環状ジメチルシロキサンの沸点

\begin{tabular}{c|c|c|c}
\hline $\begin{array}{c}\text { 低分子量環状ジメ } \\
\text { チルシロキサン }\end{array}$ & 略 号 & 沸 点 & 圧力 $(\mathrm{mmHg})$ \\
\hline$\left[\left(\mathrm{CH}_{3}\right)_{2} \mathrm{SiO}\right]_{3}$ & $\mathrm{D}_{3}$ & 134 & 760 \\
{$\left[\left(\mathrm{CH}_{3}\right)_{2} \mathrm{SiO}\right]_{4}$} & $\mathrm{D}_{4}$ & 175 & 760 \\
{$\left[\left(\mathrm{CH}_{3}\right)_{2} \mathrm{SiO}\right]_{5}$} & $\mathrm{D}_{5}$ & 210 & 760 \\
{$\left[\left(\mathrm{CH}_{3}\right)_{2} \mathrm{SiO}\right]_{6}$} & $\mathrm{D}_{6}$ & 245 & 760 \\
{$\left[\left(\mathrm{CH}_{3}\right)_{2} \mathrm{SiO}\right]_{7}$} & $\mathrm{D}_{7}$ & 154 & 20 \\
{$\left[\left(\mathrm{CH}_{3}\right)_{2} \mathrm{SiO}\right]_{8}$} & $\mathrm{D}_{8}$ & 175 & 20 \\
\hline
\end{tabular}

ンを主として用い，それらの開環重合によって高 重合度ポリジオルガノシロキサンである生ゴムを 得るのが一般的である。原料として用いられる環 状シロキサンとしては，ジメチルサイクリック ス,メチルビニルサイクリックス，メチルフェニ ルサイクリックス，ジフェニルサイクリックス， メチルトリフルオロプロピルサイクリックス等が ある。これらの環状シロキサンと種々のエンドブ ロッカーの組み合わせによって，いろいろなシリ コーン生ゴムが合成される。

図 6 にシリコーン生ゴムの重合反応を示した。 アルカリ触媒で開環反応を起こしながら行うが, 反応は平衡反応と考えられており，ポリジメチル シリコーン生ゴムではジメチル環状シロキサンが 12 14\%生成して平衡に達する.

通常は反応系を中和した後, 加熱処理によっ て，環状シロキサンを除去する。しかしながら， 生ゴムでの除去には限界があり，これらの環状シ ロキサンが原因と考えられるトラブル事例があ る2). 接点障害, 污染などで, マイクロモーター の作動不良やガラスのくもり, 塗装工程でのスポ ット現象である．表 1 に環状ジメチルシロキサン の沸点を示した．密閉状態で使用されたモーター が動作しなくなった例, OHPのガスケットに使 用されたシリコーンゴムがガラスのくもりとなる クレームになった例がある。

対策としては成形物の二次加硫が有効である 


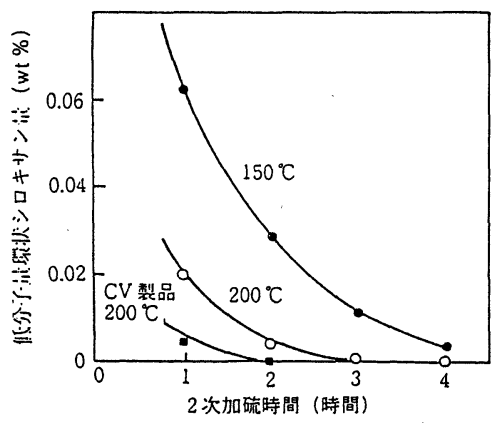

図 7 低分子量環状シロキサン $\left(\mathrm{D}_{4} \sim \mathrm{D}_{10}\right.$ 計 $)$ の量と二次加硫条件 (試料厚み： $2 \mathrm{~mm}$ )

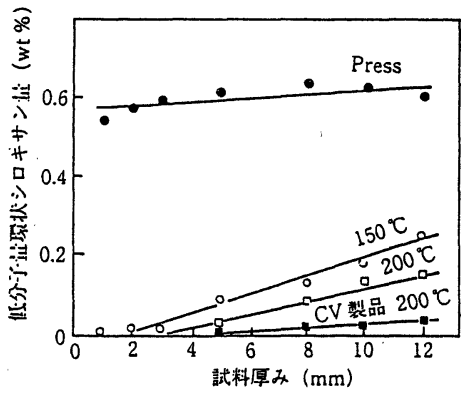

図 8 低分子量環状シロキサン $\left(\mathrm{D}_{4} \sim \mathrm{D}_{10}\right.$ 計 $)$ の量と試料厚みの関係 (二次加硫時間： 4 時間)

が，成形物の厚みや二次加硫温度，オーブンへの 成形物の投入量などで影響を受けるケースもあ り，注意が必要である．汎用シリコーンゴムにお ける二次加硫の影響を図 7 と図 8 に示した。これ らの環状シロキサンの除去量は当然，成形物の収 縮にも影響を与える。金型の設計が実際の要求の サイズと合わず，トラブルになる事例はしばらく なかったが，寸法公差が厳しくなった最近また多 くなっているようである.シリコーンゴムコンパ ウンドの製造段階で低分子物をできるだけ除去 し, 後工程で線収縮率調節剂を添加し， 2 次加硫 で除去するとの特許がある ${ }^{3)}$. シリコーンゴムは 列理方向によって縮み量が変化することはない. ただ投入重量, プレフォームの大きさ，硬化温 度，射出圧によって影響を受ける１１次加硫で州 イズが合わなくなった製品を 2 次加硫で調節する ことはできない，架橋密度で製品のサイズは決ま

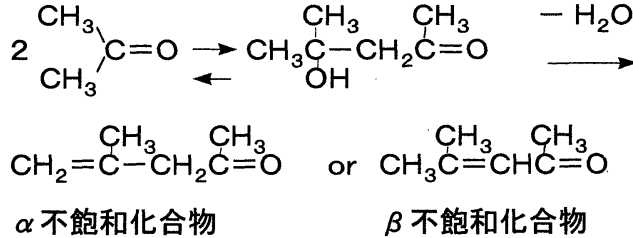

図 9 黄変原因化合物の生成反応

ク，2 次加硫は低分子物を除去するためと考えて いる.

沉用タイプのシリコーンゴムでは黄色に変色す る現象があり，2次加硫によって透明性が悪くな ってしまう．黄変防止対策シリコーンゴムが上市 されている．水素を側鎖にもつポリメチルハイド ロジエンシロキサンを含む硬化剤を用いることに よって，シリカ中に含まれる不純物の酸化反応を 抑制し，黄変を防止すると考えている。ジアルキ ルパーオキサイドの分解でアセトンが発生，これ がアルドール縮合し，脱水して共役系化合物を生 成, これが黄変の原因であり，シリコーンゴム中 にアルカリ性剂を含有させて防止するという特許 が出願されている4). 考えられる反応機構を図 9 に示した. 変色しない過酸化物の種類を選択し, 色彩色差計(ミノルタカメラ㑣)製, 商品名 $\mathrm{CR}$ 200)による測定で，黄方向の色相と彩度を表す数 值の小さいシリコーンゴム配合が適切とした特許 もある5

\section{4 異 物}

シリコーン生ゴムに補強充てん剤と可塑剂(分 散助剂, 分散促進剂とも呼ばれる)を加え混練し, ベースを作成する，補強充てん剂としては，耐熱 性に優れ，高温でもシリコーンゴム分子を侵さな いものとして，主に合成シリカが用いられる．合 成シリカには，乾式シリカ(ヒュームドリシカ) と 湿式シリカがある。乾式シリカは湿式シリカに比 べ，はるかに増粘性が高く，吸湿性が低く，補強 性があり，電気電子用途へのシリコーンゴム用に 適している. 可塑剂は補強充てん剂の分散促進, 可塑化戻りの防止，シェルフライフ向上等のため に用いられる。コンパウンド $\mathrm{U}(\mathrm{U}-$ ストックとも いう)は，ベースに更に，準補強充てん剤，増量 充てん剂，添加剂などを加え混練したもので，ま だ加硫剤が入っていない加硫剂未配合コンパウン ドである(一般に，加硫剂を混練したものとの区 
別を明確にするために，品番のあとにアルファべ ット “U”を表示する. $\bigcirc 0 \bigcirc \bigcirc$ U。 また，Uの 後に他のサフィックスをつける場合もある). シ リコーンゴムの加硫であるが，大別して，ラジカ ル反応型と付加反応型がある. 最も一般的で実用 的なのは, ラジカル反応型であり, 有機過酸化物 を加硫剤として用いる．ラジカル反応には，他に 放射線照射を利用する場合もある。加硫剂の種 類, 添加量はシリコーンゴムの物性に大きく影響 するので, 成形条件, コンパウンドの種類, 要求 特性, 用途等に合わせて選択することが必要であ る.これらの工程のどこかで異物が混入するトラ ブルがある．シリコーンゴムは合成ゴムに比較し て低粘度であり，異物や大粒径の粉末などにせん 断がかかりにくく，粉砕されにくい，またカーボ ンで黒く着色されるケースが少ないため，異物が 目立つ場合も多い，最近ではロールなどで表面精 度が厳しくなり，従来の品質では異物でないもの が除去を要求される時代である。対策としては原 料の厳選，紙袋入りの包装を避けること， ろ過工 程の充実などがあるが，分析手段によって，原因 を特定することも有力な解決方法である，液状の シリコーンゴムの事例で，シリコーンゴムを搬送 するポンプのパッキンが成形物中に混入したトラ ブルがあった．対策が効果なく，分析を詳細にや ったところ特定できたケースである.シリコーン ゴムは充てん剂との分離が可能なこと, 透明であ ること, 老化防止剂, 加硫促進剂などの添加剂を 用いることが少ないこと，などから原因の特性は 他の合成ゴムと比較すると容易と考えられる。し かし, 原料に由来する異物も残念ながら皆無とは いえず，製造工程の改善，更なる原料の厳選など 努力が必要と認識している.

\section{3. 練りエ程でのトラブル}

練り用の 2 ロールはめっきが不可欠である。シ リコーンゴムの練りは冷却が必要であるため，め つきなしでは夏の結露で錆が生じる。またプレフ オームがロールに粘着し, 均一な厚みのプレフォ 一ムが得られない．回転比も通常の合成ゴム用で はせん断力がかからず，分散不良を招くため， $1: 1.4$ の回転比のロールを加硫剂や顔料の混練 用に推奨している。

加硫剤や顔料についてはシリコーンゴムとの練 りを考慮したものがシリコーンゴムメーカーより
商品化されている，練りによるトラブル，分散不 良を防止するためにも使用を推奨したい. 合成ゴ ム用の顔料マスターバッチで色合わせし，サンプ ルでは問題なかった(分散しやすかった)ものが, 量産の大きなロールになったところ顔料の塊が分 散せず，トラブルとなった. 是非最初からシリコ ーンゴム用マスターバッチで色合わせしていただ きたい.シリコーンメーカーではサービスとして やってくれるはずである.

シリコーンゴムは未加硫ゴムの状態で極めて静 電気を帯びやすい. エボナイトよりもプラスに帯 電しやすいといわれている．特に乾式シリカ使用 シリコーンゴムにおいては電気絶縁性が $10^{16}$ $\Omega \mathrm{cm}$ 以上であり，引火性の液体や加硫剂で揮発 性の高いものを 2 ロールで添加する場合静電気に よる発火に注意することはもちろんであるが，空 気中のほこり，ダストなどが表面に付着してしま う. 空気中に合成ゴム用の老化防止剂, 加硫促進 剂などが浮遊している環境は避けて頂きたい。

最近，白金触媒を用いる付加反応や過酸化物の 選択により，高速加硫が可能となってきた，合成 ゴムと成形コストで勝負できる領域である。しか し，コンタミによる加硫トラブルがある．付加反 応ではアミン，リン，硫黄などを含む成分がある と硬化阻害を受けることがある。これらの物質は 白金触媒への配位力が強く，触媒毒となる，わず かの量であっても被毒する場合がある．コストダ ウンの要求から白金触媒の量を減量した配合で, ポリエチレンシートに包んで保管したところ，経 時で徐々に硬化遅延現象が発生した。透明シート から硫黄，リンがブルーシートから硫黄のみ検出 された．白金量を元に戻すことでトラブルは解決 したが，值段は戻らなかったという経験がある. また合成ゴムに用いられる老化防止剂はラジカル 捕促剂であることが多く，シリコーンゴム加硫剂 の過酸化物の反応を遅くすることがある．過酸化 物を増量することで解決する場合もあるが，是 非, 合成ゴムの工程とは別工程とし, 同じ工場内 でも別の部屋とすることを推奨したい. シリコー ンゴムはナイーブ，センシティブなゴムなのであ る。

過去に練り終わったコンパウンドをストーブの ある部屋で保管していたところ，不完全燃焼のス スが表面に付着(濃い色のものであったため発見 できず)し，加硫後，変色して大騒ぎとなったこ 
とがあった．条件に変化のないことは確認したつ もりであったが，まさかストーブとは気がつかな かった事例である. 部屋のあちこちにコンパウン ドを放置して加硫したところ，ストーブに近い試 験片ほど変色が大きく，原因を特定することがで きた。

\section{4 . 成形上のトラブル}

成形には，目的に応じて次のような成形法があ る.

\section{1 圧縮成形}

圧縮成形の場合，金型は完全な成形品を得るた めおよび仕上げ加工のために，ばり溝をつけた設 計にしてあるのが一般的である．金型への材料の 仕込みは，一般的には手で行うが，多数個取りの 場合などは，スコーチを防ぐため充分な注意が必 要である. 成形温度や時間は, 加硫剤の種類, 成 形品の肉厚や形状などによって異なる．成形圧力 は，材料が金型のすみずみに流れる条件であれば よいとされるが，シリコーンゴムでは一般に 1.5 $\mathrm{MPa}$ の成形圧力があれば充分である。また，金 型からの取出しは，一般には熱い金型からすぐに 取り出すが，肉厚成形品，布入り成形品などは金 型を冷却してから取り出すほうがはく離, 変形な どの防止に効果のある場合がある．スコーチ防止 に金型を冷却する場合, 水道水は避けるべきで, $\mathrm{Ca}$ が金型に蓄積し，離型性が悪化する，蒸留水 の使用を推奨したい. 離型剂の塗布も意外と難し く, 近距離から吹き付け, 全部跳ね返ってしまっ て離型効果が発現しなかったという話もある。ま たスコーチなどのトラブルを防ぐためには加硫剤 の選択が重要となる。圧縮成形は内部離型剂の進 歩, 金型の表面処理の進歩などからトラブルの少 ない成形方法である。

\section{2 射出成形}

射出成形は型締めされた金型のなかにノズル $\rightarrow$ スプルーーランナーを通じ，高速で材料を充てん し，成形する。この方法は成形サイクルが速いこ と，ロスが少ないことが利点である。シリンダー 温度は通常は常温で成形するが，加硫剤の種類に よっては，80〜 90ㄷになっても悪影響はない。成 形時間は，成形品の形状などにより異なる。射出 時間は，成形サイクル短縮のためには短いほどよ いが，ノズル，ゲート部での焼けなどの対策上, $5 \sim 10$ 秒が一般的である．また，射出圧は，一

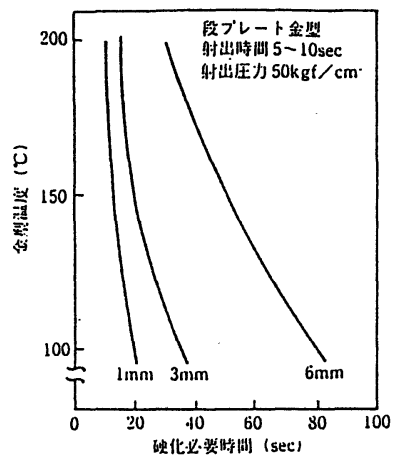

困10 金型温度と硬化時間

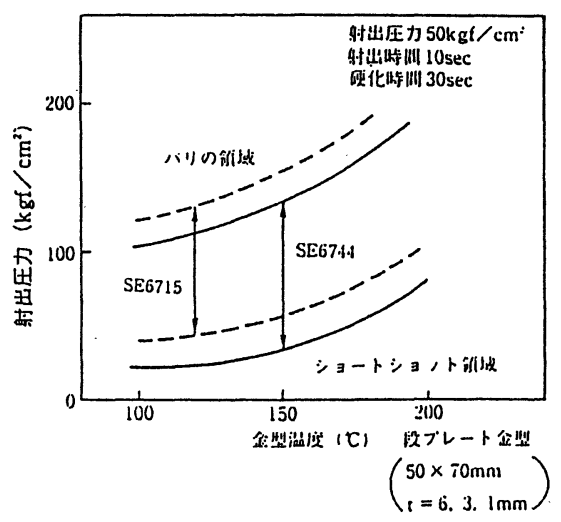

困11 成形領域

般的に 3.5 15 MPa の範囲が適当とされている. 金型温度と硬化時間の関係を図 10 に，成形領域 について図 11 に示した。 また過去の成形不良の 原因とその対策について表 2 によとめた。

\section{3 トランスファー成形}

トランスファー成形は, 型流れの悪い金型, 空 気だまりの起こりやすい金型で成形する場合に有 効な成形方法とされる，更に，インサート部品の ある成形品の場合にも最適である。トランスファ 一成形用のポットは金型に取りつけてある場合 と，取りはずし可能の設計にする場合とがある が，ポットのなかのゴムの再利用を考える場合 は，取りはずし式にする必要がある，ゲート形状 の工夫がトラブル防止に効果のある場合もある.

\section{4 押出成形}

チューブ，ロッド，ガスケット，シール，電線 等の押出成形が容易である。押出成形は, 一般の 
表 2 成形不良の原因とその対策

\begin{tabular}{|c|c|c|}
\hline 現 象 & 因 & 対 \\
\hline ふくくれ & $\begin{array}{l}\text { ・硬化不足 } \\
\text { ・成形圧不足 } \\
\text { - 空気が型から抜けない } \\
\text { ・肉厚の不均一 } \\
\text { ・加熱不均一 }\end{array}$ & $\begin{array}{l}\text { 硬化時間を長くする. 金型温度を高くする. } \\
\text { 圧力を增す. 特に多数個取りの場合は重量のバランスを考慮する. } \\
\text { 空気拔きを充分行う. 型締め時間を長くする. 空気抜き溝をつけ } \\
\text { る. 真空成形方法を採用する. } \\
\text { 金型温度を下げ, 加圧時間を長くする. } \\
\text { 加熱装置の調整. }\end{array}$ \\
\hline $\begin{array}{l}\text { 内部の巣 } \\
\text { (ボイド) }\end{array}$ & $\begin{array}{l}\text { ・空気拔き不足 } \\
\text { ・硬化不足 }\end{array}$ & $\begin{array}{l}\text { 空気抜きを充分行う．金型温度を上げる． } \\
\text { 硬化時間を長くする. }\end{array}$ \\
\hline $\begin{array}{l}\text { 白化現象, } \\
\text { かすれ等表 } \\
\text { 面の欠陥 }\end{array}$ & $\begin{array}{l}\text {-金型温度高すぎる } \\
\text { ・空気抜き不充分 } \\
\text { ・型開き早すぎる }\end{array}$ & $\begin{array}{l}\text { 金型温度を下げる. } \\
\text { 空気拔きを充分行う. 真空成形方法を採用する. } \\
\text { 型開き時間を長くする. }\end{array}$ \\
\hline 色むら & $\begin{array}{l}\text { •練り不足 } \\
\text { •金型温度高すぎる }\end{array}$ & $\begin{array}{l}\text { 材料を変更する．練り順序を変更する．練り時間を長くする． } \\
\text { 金型温度を下げる. }\end{array}$ \\
\hline $\begin{array}{l}\text { ウェルドマ } \\
\text { ーク }\end{array}$ & $\begin{array}{l}\text { ・金型温度高すぎる } \\
\text { ・ゲートとウェルドジョ } \\
\quad \text { イント間の距離が長い } \\
\text { ・成形圧不足 } \\
\text { ・融着部の空気抜けが悪 } \\
\text { い } \\
\text { ・ゲートが小さい }\end{array}$ & $\begin{array}{l}\text { 金型温度を下げる. } \\
\text { ゲートの位置を変更する. } \\
\text { 成形圧を增す. } \\
\text { 空気抜きをつける. 真空成形方法を採用する. } \\
\text { ゲートを大きくする. }\end{array}$ \\
\hline 光沢不良 & $\begin{array}{l}\text { ・硬化不良 } \\
\text { ・金型表面のめっき不足 }\end{array}$ & $\begin{array}{l}\text { 硬化時間を長くする. } \\
\text { よく磨いて硬質クロムめっきを行う。 }\end{array}$ \\
\hline 離型不良 & $\begin{array}{l}\text { ・硬化不足又は過多 } \\
\text { ・型きず, 型表面状態不 } \\
\text { 良, テーバー不足 } \\
\text { ・表面温度分布不均一 }\end{array}$ & $\begin{array}{l}\text { 金型温度, 硬化時間の調節. } \\
\text { 金型を修理する. } \\
\text { 加熱方法を検討する. }\end{array}$ \\
\hline ノズル洩れ & $\begin{array}{l}\text { ・材料の流れが大きすぎ } \\
\text { る } \\
\text { ・背圧が高すぎる }\end{array}$ & $\begin{array}{l}\text { 洩れ防止ノズルの検討. } \\
\text { 背圧を低くする. }\end{array}$ \\
\hline
\end{tabular}

有機ゴムと大差はないが, 細部では多少異なって いる．シリコーンゴムの押出成形は，押出機中で の流れが良いという利点があるが，口金からの押 出後のスウェリング(膨張) と, グリーンストレン グス(生ゴム強さ)の低さによる押出後の変形しや すさの 2 点について注意が必要である。また，押 出機中での発熱は, 充分に注意する必要がある. 通常 $50^{\circ} \mathrm{C}$ 程度の温度でも, スコーチ, 加硫剤の 失効は問題ない，温度とともに，異常滞留の防止 などは，通常の押出成形と同様な注意が必要であ る. 熱風加硫は押出品を連続加硫する場合に, 最 も一般的に使用される方法である。一般に $315 \sim 430^{\circ} \mathrm{C}$ 程度の熱風炉のなかを押出品を通過さ
せることにより加硫する．肉薄品では数秒で加硫 が完了する。押出し成形では外観不良(すじの発 生やボイド)のトラブルがある、スクリューを摩 耗させる可能性のある石英入りの材料を避けるこ と, 吐出性の良い材料を選択すること, 可塑度が 高く練りで混入したエアーボイドを押出すタイプ のシリコーンゴムが良好な結果をもたらすようで ある. 加硫剤混練後, 一日程度放置することでボ イドがなくなる事例があった。なお湿式シリカを 含有するシリコーンゴムは発泡現象がみられ，押 出し成形には不適とされる.

従来はアシル系の過酸化物を用いる押出し成形 が大半であったが，白金触媒や反応抑制剂の進歩 
で，付加反応による押出し成形も増加している. アシル系過酸化物ではブルームに注意する必要が あるが, 適切な 2 次加硫を行えば問題ない. 保存 時に硬化してしまうトラブルは減少している。

\section{5 スポンジ成形}

シリコーンゴムスポンジは, 未加硫ゴムに発泡 剤を加え加熱すると, 発泡剂が分解して気体が発 生し, セルを形成し, 同時に加硫剤が働いて硬化 し成形される。成形法には自由発泡法と, プレス 発泡法の二方法があるが，一般にプレス発泡スポ ンジは自由発泡スポンジに比べ, 寸法精度が高 く, 密度が高い, かつ表面皮膜の厚いスポンジの 成形ができる、いずれのスポンジ成形法において も, 加硫速度と発泡剂の分解速度のバランスをと ることが重要なポイントとなる，ただ均一な発泡 のスポンジを得ることは難易度が高く，多くの場 合成形メーカーのノウハウとなっているようであ る.

\section{6 シリコーンゴムの接着}

金属, ガラス, 陶磁器, プラスチック, 布, シ リコーンゴム等と接着して使用されることがあ る. 被着体に応じて, 各種プライマーが準備され ているが，接着にかかわるトラブルもある．被着 体表面の洗浄, 脱脂が必要であり，またプライマ 一は一般に空気中の水分と反応し, 加水分解して 接着膜を作る成分があるので，保存時には水分を 遮断すること, プライマー乾燥時には $30 \sim 60$ 分 の乾燥時間と適度な湿度が重要となる．塗布厚み も厚くなるとむしろ接着が悪くなるケースもあ ク，トラブルも梅雨どきに多い経験がある，溶剤 の乾燥も考え, 排気の良好な部屋でのプライマー 塗布を推奨したい.

\section{5 . 最近のシリコーンゴムの動向}

最近の世界のシリコーンゴムの市場規模は約
70 億 US ドル程度，またシロキサンの生産量は 全世界で約 70 万 $\mathrm{t} /$ 年程度と推定されている. シ リコーンゴムはリモコン，パソコンや携帯電話の キーパッドや接点ゴムとして使用量は増大してい る. シリコーンゴムの耐久性向上の研究，シリコ ーンポリマー中のシリカの分散状態の研究などか ら屈曲回数の向上，また導電インクなども開発さ れている，低分子量の環状シロキサンを減少させ る接点障害対策品の進歩もあり，シリコーンゴム の用途は拡大している. 絶縁と導電の中間に位置 する半導電領域の製品, 高い熱伝導と低圧縮永久 ひずみを両立させた製品, 熱伝導や電気伝導と低 硬度を両立させた製品などの開発から，複写機， プリンター，ファクシミリに使用される各種ロー ルにも多く使用される時代となった．環境への配 慮からガスケット用途も注目されており, 燃焼生 成ガスにハロゲン系のものが含まれないシリコー ンゴムが注目されている．解重合反応の起きない 合成ゴムと違い, リサイクルの可能性のあるシリ コーンに更なる飛躍の機会があると期待してい る ${ }^{6)}$. シリコーンゴムのトラブルは解決と対策に ようて，技術改善の機会となるケースが多い．原 料メーカー, 成形メーカー, エンドユーザーの情 報交換，意見交換，解決への提案をより密にして 少しでも貢献できれば技術屋冥利と考え, 努力し たい.

\section{文献}

1 ）シリコーンハンドブック：伊藤邦雄編 (1990) 日刊工業 新聞社, p.301

2) 角村真一：日ゴム協誌，63，377(1993)

3 ) Ushio, Y. et al. : USP 5210126

4) 特公平 $7-81075$

5) 特開平 10-46030

6) 角村真一: 実用プラスチック事典, 産業調查会 (1993), p.286 